\title{
The Role of Perforin
}

1,2Davorka Švegar

1 Department of Hospital Infection Control, University Hospital Center Rijeka, Rijeka, Croatia

2 Alma Mater Europaea, Maribor, Slovenia

Article received: 16.07 .2020 .

Article accepted: 24.11.2020.

Author for correspondence:

Davorka Švegar

University Hospital Center Rijeka

Krešimirova 42, Rijeka, Croatia

E-mail: davorka.svegar@gmail.com

https://doi.org/10.24141/2/5/1/7

Keywords: perforin, lymphocytes, target cell, granzymes, literature

\section{Abstract}

Some literature reviews have been carried out about the role of perforin in medicine. The first step involved a systematic search to identify relevant studies published between 2001 and 2019 in the following electronic databases - EBSCOhost, Scopus, Science Direct, Web of Science, and Elsevier. By analyzing the available literature, it can be concluded that perforin plays an important role in cytoxical activity of natural killer cells (NK) and CD8+ T cell. NK and CD8+use the same mechanism for destroying target cells. This article cites the disease hemophagocytic lymphohistiocytosis (HLH) which is characterized by heavy abnormalities in the immune system. The point is that this disease is caused by perforin gene mutation. The key is the application of properly sensitized dendritic cells (DCs) because they are effective in immunotherapy against cancer. It may be effective in $\gamma$-irradiated colon cancer cell lines HT-29. Growth hormone-inhibiting hormone (GIH) induces maturation and activation of DCs. In that way, GIH-Dcs shows increased cytotoxic activity and higher perforin and granzyme expression. So, this means that theoretical research has shown that efficient activity against cancer is induced when DCs are sensitized with $\gamma$-irradiated cancer cells. In that way, through a direct increase of cytotoxicity and indirect $\mathrm{T}$ cell activation, there can beanti-tumor activity. It is suggested to continue scientific research about the role of perforin in the future. 


\section{Introduction}

Perforin is a glycoprotein responsible for formingpores in cell membrane softargeted cells. An annotation about the structure and function of human perforin was announced in 2010 (1). Its structure and mechanism are described in detail in the paper published by Monash University researchers in 2010. Jules Brodet,a Nobel prizeman, published the first hypothesis about the forming pores of targeted cells as apart of the immune response (2). Natural killer cells (NK) and CD8+positive T-cells are the main sources of perforin. Meanwhile, CD4+ positive T-cell is also capable of expressing a low quantity of perforin, when classical cytotoxic is not efficient or distressed (3). Much attention is dedicated to their role in the immune response to bacterial and viral infections, immune surveillance, and immunopathology. Besides that, perforin is involved in the pathogenesis of autoimmune diseases and alogen rejection of transplant organs (2).

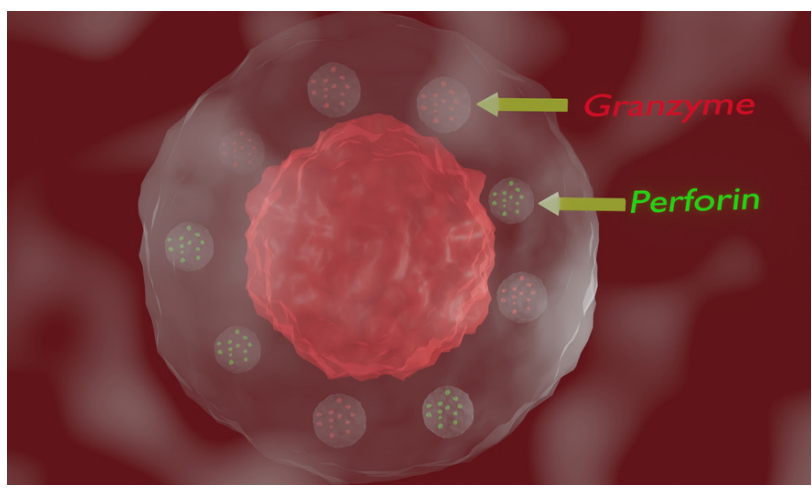

Figure 1. Perforin

Source: Shutterstock.com

Figure 1. represents cytotoxic T Iymphocyte which shows the cytotoxic substances, perforin and granzyme, in 3d illustration.

Furthermore, the purpose of this article is to understand the importance of perforin in medicine. The rationale of this article is to conduct further research about the role and use of perforin for medical purposes, as well as to motivate for further research and education about the role of perforin.

\section{Methods}

The author systematically reviewed the literature using different scientific and medical literature. National Library of Medicine (NHI) was mostly used, as well as the articles published between 2001 and 2019 in bibliographic databases EBSCOhost, Web of Science, Science Direct and Elsevier. Its structure and mechanism are described in detail in the paper published by Monash University's researchers, in detail, in 2010. Jules Brodet, a Nobel's prizeman, published the first hypothesis about the forming pores of targeted cells as a part of the immune response. The reviewed articles were obtained by using the following keywords: perforin, lymphocytes, target cell, T cell, natural killer cell, granzymes. The author then used these areas to develop a list of keywords and searched for these terms in conjunction with the keyword "perforin".

\section{The structure of perforin}

Perforin is 60-70 kDa glycoprotein. The National Protein Database indicates that it has 555 amino acids, which should give it about $70 \mathrm{kDa}[2]$. One perforin molecule consists of four domains, including two ( $\mathrm{N}$ terminal and C-terminal) which are typical for perforin and connected with its biological functions. Two other domains, located in the center of the molecule, are $20 \%$ homologous on the analogous domains in the molecular addendum (C6, C7, C8, and C9) (4). One of the homologous domains contains the sequence which enables forming two $\beta$-chains and one $\alpha$-helix structure. It is a hydrophobic domain and it may be connected with the lipid membrane of the targeted cell. Besides, perforin consists of cysteine because it is a rich domain which is homologous with low-density lipoprotein (LDL), receptor B type, and forerunner for epitel growth's factor (1). The same author cites: „A 14-nm channel is formed by approximately 20 perforin molecules; however, it was shown that even 3-4 perforin molecules are able to form an efficient pore" (2). A polymerized molecule of perforin makes cylindrical and hydrophobic channels that enable free, unselective, and passive transport of ions, water, small molecules surfactants, and enzymes. As a consequence, channels disturb protective barriers of the target cell and destroy the integrity of the target cell (6). 
Also, the phenotypic and functional changes in human DCs sensitized with $\gamma$-irradiated colon cancer cell-line HT-29 (GIH) was investigated by Sun Kyung et al. GIH-sensitized DCs showed increased cytotoxic activity against HT-29 through higher expression of perforin and granzyme $B$. They further induced expression of effector cytokines, cytotoxic molecules, and mucosal-homing receptor in autologous T-cells. Conclusively, these results suggest that effective anti-cancer activity is induced when DCs are sensitized with $\gamma$-irradiated cancer cells via both direct augmentation of the cytotoxicity and indirect activation of T cells. Gamma-irradiation-induced apoptotic cancer cell-line HT-29 (GIH) induced maturation and activation of dendritic cells (DCs). The other conclusion of the research showed that GIH-sensitized DCs showed an enhanced cytotoxic activity against live HT-29, that GIH-sensitized DCs activated autologous $T$ cells to express cytokines, cytotoxic molecules, and mucosal-homing receptors, and DCs sensitized with gamma-irradiated cancer cells could be an effective anti-cancer therapeutic (7).

\section{The role of perforin}

Perforin can be polymerized and it can form channels in in the targeted cell membrane. Perforin polymerization and pore formation require $\mathrm{Ca}^{2+}$ ion. They are responsible for the transformation from unactive, globular form to active perforin which afterward can be infiltrated in the cell membrane. The processes of embedding and polymerization depend on different factors, including temperature, platelet-activating factor (PAF), and the activation of membrane receptors. Calreticulin is an important cytolytic granules' enzyme that has a role in supporting perforin protein. It protects from activation and degradation in the way that keeps in glomerular form. It is bounded by $\mathrm{Ca} 2+$ and inhibited spontaneous perforin polymerization inside granules. Perforin binds target cells through membrane phospholipids. Phospholipids can bind $\mathrm{Ca} 2+$ ions and increase perforin affinity for the target cell membrane.

The pores formed by perforin interfere with the cell membrane and allow free influx and efflux of ions and polypeptides. As a result, ion homeostasis is disrupted and necessarily leads to the development of tonic shock. Indirectly, activation of proapoptotic pathways and DNA degradation leading to cell death is induced (5). Calcium ions can be responsible for inhibition of perforin polymerization and can cause blockage of transmembrane channels. That kind of phenomenon is observed in low $\mathrm{pH}$ and increased concentration of calcium ions. Protein S inhibits perforin.Protein S is a glycoprotein which inhibits lythical activities for complementary components.Because of structural homology between components for perforin complement and C9, protein S can inhibit perforin functions. Protein $\mathrm{S}$ binds on the perforin spot at the cell membrane and therefore inhibits the creation of pores (6).

Perforin plays an important role in cytotoxic activity of natural killer cells (NK) and CD8+ T cell. NK and CD8+ use the same mechanism for destroying cell membranes but the activation ways differ. NK cells, unlike CD8+ cells show spontaneous cytotoxicity towards target cells. This depends on perforin and discharge of granzyme B. The first step in the cytotoxic process is the identification of the target cell which can be specific (in the case of T CD8+ cell). Unlike T cells, NK cells do not identify major histocompatibility complex(MHC) bounded antigens. The next step is the formation of lithic synapses between effectors and the target cells. The contact between these two cells makes changes in the structure of the effector cell. Cell organelles (such as microtubules, Aparati Golgi, and cytological granules) are translocated toward the synapse. The released granules contain perforin and granzyme $B$ which are involved in the cytotoxic reaction in the target cells (8). NK cells and cytotoxic cells are resistant to other cytotoxic NK cells' activities. The inhibition of pore formation in these cells is most likely connected with decreased binding of perforin on the surface of their cell membrane.

Figure 2 shows cytotoxic T cellwhich regulates immune responses, releases the perforin and granzymes, and attacks infected or cancerous cells. Through the action of perforin, granzymes enter the cytoplasm of the target cell and lead to apoptosis cell death.

The most sensitive method for intracellular perforin detection is flow cytometryflow cytometry enables the proof that there is a perforin expression through superficial tags which identify specific cell population. Also, flow cytometry is used to validate perforin colocalization with granzyme B in cytotoxic granules polarized to the immunological synapse, and to assess the expression of perforin in cytotoxic $T$ Iymphocytes at various stages of activation. The sensitivity of this technique also allowed to distin- 


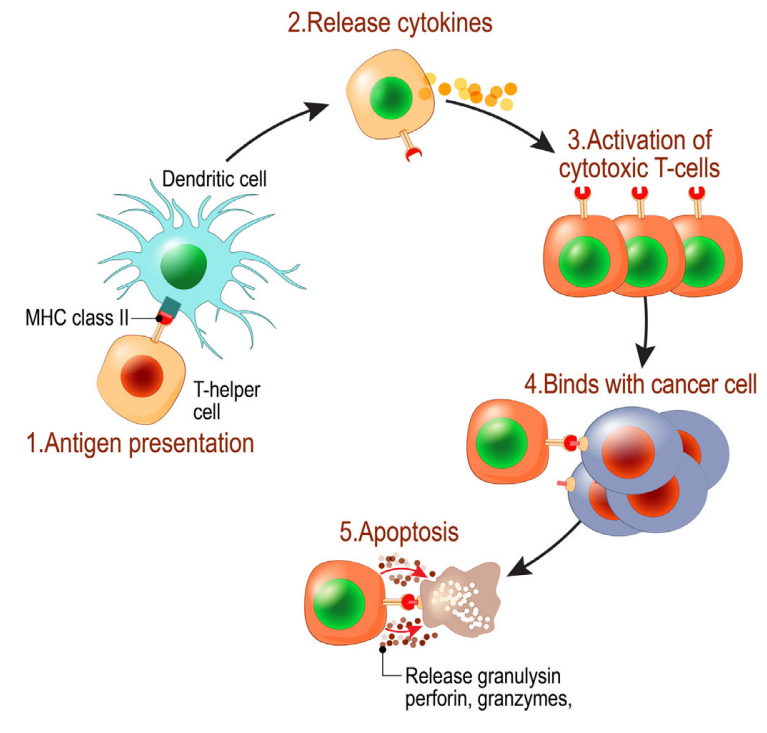

Figure 2. Cancer and cytotoxic T cells

Source: $123 r f . c o m$

guish perforin levels in Prf1(+/+) and Prf1(+/-) mice (22). Hemophagocytic Lymphohistiocytosis $(\mathrm{HLH})$ is a disruption characterized by heavy abnormalities connected with uncontrolled hyperactivation in the immune system. Family (Hemophagocytic Lymphohistiocytosis) HLH can be caused by a characteristic perforin gene mutation. It proves that gene shortcomings cause the lack of perforin. It can be a significant cause of HLH development, that is why, perforin expression in CD16 + CD56 + NK cells is included in the HLH diagnosis protocol (10).

Meanwhile, partial lack in perforin production can be the cause of increased sensitivity to hematological malignancies development (leukemia and lymphoma). Detailed analysis of patients with mutation PRF1 and with postponed symptoms typical for HLH, (Hemophagocytic Lymphohistiocytosis) showed that half of the examined patients had developed primary hematological diseases. The cytometric analysis showed that abnormal binding of perforin on the target cell (neoplastic cell) is the main resistance mechanism to perforin. The mutation in both perforin's allele gens may be the cause of uncontrolled lymphoproliferation. Research on knockdown mice model showed that those animals were more vulnerable to neoplastic diseases than those with normal perforin content. It confirms the significant role of perforindependent cytotoxic mechanisms in the anti-tumor response. The role of perforin and granzyme $B$ in inhibiting tumor growth and disease progression suggests that this mechanism may become a therapeutic target in the future (11).

\section{Colorectal cancer}

A host against a tumor is thoroughly confirmed in the defense mechanism in the content for the role of tumor-infiltrating Iymphocyte (white blood cell that has migrated to a tumor, TIL). It is known that cytotoxic lymphocytes CTLand NK directly kill tumor cells.In the tissue of perforin, cancer can be extracted from CTL (cytotoxic T Iymphocytes) and NK cells and have an important role in antitumor activity.

In colorectal cancer stroma, perforin (PRF) cells have been more numerous nearby tumor infiltration than in normal mucosa membrane. Also, the number of poreforming protein (PFP) cells have decreased following tumor progression. Double coloring of PFP+cells has shown that PFP in TIL (tumor-infiltrating Iymphocyte) mainly produces CD8+ cells but not CD16 cells which were a different medical finding from that from PBL (peripheral blood lymphocyte). Nakanishi et al. explain that PFP+ cells were most numerous in Dukes $A$ and decreased in number according to the progression of tumours (12). The PFP+ cells in TIL exhibited the same phenotypes as those in PBL but the PFP+ cells were more numerous in CD8+ cells than in CD16+ cells at all stages. This study represents the first evidence that PFP is mainly secreted from CD8+ cells in tumour tissues. It is hypothesised that the decrease in the number of PFP+ cells in accordance with tumour progression may reflect the suppression of the hosts local immunity (12).

In that way, this supports previous reports that CD cells have an important role in curbing tumor growth (15). A lot of researchers reported that the number of CD8+ cells or CD16 cells in TIL has got the tendency to be reduced in progressive cancer (13). PFP can also have an important role in the defense mechanism against cancer in coordination with other factors. The data about NK cells in periferal blood of the patients with colorectal carcinoma can be found in the literature in the National Library in Medicine (NIH). The number of NK cells in periferal blood is significantly reduced in patients with disseminated cancer forms. Meanwhile, there are contradictory data about the 
reduction and increase of NK cells in periferal blood of patients with colorectal cancer. Furthermore, following data from Carlsten et al., 1-2 \% NK cells of the donors with a good health status have superficial term CD107a. It is a study mentioned (14) in the literature that an occurrence of CD107a on the surface is believed as a sign of NK cells degranulation and a patient's malignant tumor response to intrinsical environmental factors. The functional activity of periferalNK cells in the patient with cancer is more significantly changed in comparison with the donor of a good health status. Namely, the percentage of CD56+CD107a+GB-PF cells is reduced, otherwise the percentage of CD56+CD107a+GB+PF+ cells is increased. The population of CD56+CD107a+GB-PF cells should have to be thought of as a group of functionally incorrect cells. These cells do not contain active cytotoxic enzymes in granulations whereas superficially expressed 107 a protects NK cells from apoptosis after degranulation $(14,15)$.

\section{Conclusion}

Perforin is a cytotoxic protein thatlymphocytes secrete to destroy virus-infected cells and tumor cells. It also plays an important role in the activity of cytotoxic $T$ cells and natural killer cells as it causes a series of abnormal body cells and an elimination of cells infected with the virus and tumor. Upon degranulation, PRF inserts itself into the target cell's plasma membrane, forming a pore, in accordance with research of L.-F. Wang et al..The subsequent translocation of pro-apoptotic granzymes (including granzyme $B, A$, $M$ et al.) into the cytoplasm provides the proteases with access to numerous protein substrates that promote apoptosis after cleavage. These proteases are believed to be the main executioners of target cell apoptosis. Although the PRF and granzyme components are both critical to this process and in some way involved in inducing cell death in target cells, the inhibition of tumor growth could still be efficient in granzyme-deficient mice. It is unclear whether PRF alone can suppress tumors. In this study, we discovered that forced ectopic expression of PRF alone, in the absence of granzymes, could mediate cell death in cancer cells. Although PRF and granzyme's components are critical for this kind of process and in some way, cause cell death in the target cell and inhibit tumor growth. It is not clear that PRF can suppress tumors alone, Takinginto consideration scientific facts, it may be possible to use PRF as pro-apoptotic gen for anti-tumor therapy (17).

Digestive malignancies still occur at persistently high rates, and disease progression in these kinds of cancers is associated with the escape of tumor disease surveillance.

So, NK cell dysfunction can be responsible for this phenomenon, but there is no clear explanation about the relationship between tumor immune surveillance in digestive malignancies and NK cell dysfunction.

It is clear that mutation of function loss in genetic PRF decoding significantly reduces the ability of cytotoxic T lymphocytes and natural killer cells to kill target cells by that way causing immunosuppression and impairing the immune system (18).

It is not yet proven that NK cells have a key role in suppression of the development of spontaneous metastases in patients with cancer. Despite a wide range of studies, it has not yet been clear whether NK cells play a key role in suppressing the development of spontaneous metastases in cancer patients. Despite a wide range of studies, it remains unclear to date to what extent primary tumor growth along with the formation of distant metastases and NK cell activity affect each other.

The increase of primary tumor's size in patients with colectoral carcinoma results in the increased share of activated periferal blood NK cells, cytolytic granules which contain enzymes GB and PF. Even though besides producing lymphogenic metastases, hematogenic metastases in the liver as the main form of cancer progression for colectoral carcinoma, the presence or absence of lymphogenic spread, has no significant impact on perforin quantity and NK cell subpopulation (19).

Properly sensitized dendritic cells (DCs) may also be effective in immunotherapy against cancer. It may be effective in $\gamma$-irradiated colon cancer cell lines HT-29 (GIH, growth hormone-inhibiting hormone). Growth hormone-inhibiting hormone induces maturation and activation of DCs. In that way, GIH-DCs shows increased cytotoxic activity and bigger perforin and granzyme expression. Arguably, these results show that efficient activity against cancer is induced when 
DCs are sensitized with $\gamma$-irradiated colon cancer. In that way, through a direct increase of cytotoxicity and indirect $T$ cell activation so we may act in an antitumor way (20).

\section{References}

1. Voskoboinik I, Whisstock JC, Trapani JA. Perforin and granzymes: function, dysfunction and human pathology. Nat Rev Immunol. 2015;15(6):388-400.

2. Osinska I, Popko K, Demkow U. Perforin: an important player in immune response. Cent Eur J Immunol. 2014;39(1):109-5.

3. Tschopp J. Perforin. In: Delves P, Roitt I, editors. Encyclopedia of Immunology. 2nd ed. London: Academic Press; 1998.

4. Mak TW, Saunders ME. The Immune Response:Basic and Clinical Principles. London: Elsevier; 2006.

5. Kägi D, Vignaux F, Ledermann B, Bürki K, Depraetere $V$, Nagata $S$, et al. Fas and perforin pathways as major mechanisms of T cell-mediated cytotoxicity. Science. 1994;265(5171):528-30.

6. Voskoboinik I, Dunstone MA, Baran K, Whisstock JC, Trapani JA. Perforin: structure, function, and role in human immunopathology. Immunol Rev. 2010;235(1):35-54.

7. Trapani JA, Smyth MJ. Functional significance of the perforin/granzyme cell death pathway. Nat Rev Immunol. 2002;2(10):735-47.

8. Kim SK, Yun $\mathrm{CH}$, Han SH. Enhanced anti-cancer activity of human dendritic cells sensitized with gammairradiation-induced apoptotic colon cancer cells. Cancer Lett. 2013;335(2):278-88.

9. Hoves S, Trapani JA, Voskoboinik I. The battlefield of perforin/granzyme cell death pathways. J Leukoc Biol. 2010;87(2):237-43.

10. Sullivan KE, Stiehm ER. Stiehm's Immune Deficiencies. USA: Elsevier; 2014.

11. Armas LR, Podack ER. Natural killer cytolytic activity. In: Lotze MT, Thomson AW. Natural Killer Cells. London: Elsevier; 2010.
12. Nakanishi H, Monden T, Morimoto H, Kobayashi T, Shimano T, Mori T. Perforin expression in Iymphocytes infiltrated to human colorectal cancer. $\mathrm{Br} J$ Cancer. 1991;64(2):239-42.

13. Czystowska M, Strauss L, Bergmann C, Szajnik M, Rabinowich $\mathrm{H}$, Whiteside TL. Reciprocal granzyme/perforin-mediated death of human regulatory and responder $T$ cells is regulated by interleukin-2 (IL-2). J Mol Med (Berl). 2010;88(6):577-88.

14. Ogata M, Ota Y, Matsutani T, Nanno M, Suzuki R, Itoh T. Granzyme B-dependent and perforin-independent DNA fragmentation in intestinal epithelial cells induced by anti-CD3 mAb-activated intra-epithelial lymphocytes. Cell Tissue Res. 2013;352(2):287-300.

15. Zhang Y, Liu Y, Xu Y. Interleukin-24 Regulates T Cell Activity in Patients With Colorectal Adenocarcinoma. Front Oncol. 2019;9:1401.

16. Arias M, Martínez-Lostao L, Santiago L, Ferrandez A, Granville DJ, Pardo J. The Untold Story of Granzymes in Oncoimmunology: Novel Opportunities with Old Acquaintances. Trends Cancer. 2017;3(6):407-422.

17. Willenbring RC, Johnson AJ. Finding a Balance between Protection and Pathology: The Dual Role of Perforin in Human Disease. Int J Mol Sci. 2017;18(8):1608.

18. Poggi $A$, Zocchi MR. Human natural killer lymphocytes through the engagement of natural cytotoxicity receptors and NKG2D can trigger self-aggression. Autoimmun Rev. 2007;6(5):295-9.

19. Durgeau A, Virk Y, Corgnac S, Mami-Chouaib F. Recent Advances in Targeting CD8 T-Cell Immunity for More Effective Cancer Immunotherapy. Front Immunol. 2018;9:14.

20. Kulikova EV, Kurilin VV, Shevchenko JA, Obleukhova IA, Khrapov EA, Boyarskikh UA, et al. Dendritic Cells Transfected with a DNA Construct Encoding Tumour-associated Antigen Epitopes Induce a Cytotoxic Immune Response Against Autologous Tumour Cells in a Culture of Mononuclear Cells from Colorectal Cancer Patients. Scand J Immunol. 2015;82(2):110-7.

21. Wang LF, Wang F, Li JT, Wen WH, Zhao J, Jia LT, et al. Ectopically expressed perforin-1 is proapoptotic in tumor cell lines by increasing caspase- 3 activity and the nuclear translocation of cytochrome C. PLoS One. 2012;7(7):e40639.

22. Brennan AJ, House IG, Oliaro J, Ramsbottom KM, Hagn $M$, Yagita $H$, et al. A method for detecting intracellular perforin in mouse Iymphocytes. J Immunol. 2014;193(11):5744-50. 


\section{Abbrevations}

C terminal- the end of the peptide chain carrying the free alpha carboxyl group of the last amino acid, conventionally written to the right

C6- Complement component 6 (C6 protein) in the complement cascade system of immune proteins (native immunity)

C7- C7 protein, engineered transcription factors

c8- c8 complex, three proteins involved in the complement system (part of the immune system)

\section{C9- C9 (Complement component 9), a protein}

$\mathrm{Ca} 2+-\mathrm{A}$ gene on chromosome 8q22 that encodes an isoenzyme of carbonic anhydrase, a zinc metalloenzyme that catalyses the reversible hydration of carbon dioxide. Carbonic anhydrase 2 is essential for bone resorption and osteoclast differentiation

CD 107a- cluster of differentiation 107a

CD 16- cluster of differentiation 16

CD 4-cluster of differentiation 4

CD 56- cluster of differentiation 56

CD 8 T- cluster of differentiation 8 trombocyte

CTL- Cytotoxic T-Lymphocyte (immunology)
DNA- deoxyribonucleic acid

DCs- dendritic cells

$\mathrm{GIH}$ - growth hormone-inhibiting hormone

HLH- Hemophagocytic Lymphohistiocytosis

LDL- low-density lipoprotein (Biochemistry)

MHC- major histocompatibility complex, minor histocompatibility complex.

$\mathrm{N}$ terminal-the amino ( $\mathrm{NH} 2$ ) end of a polypeptide chain, conventionally written to the left

NK-Natural killer cell

PAF- platelet-activating factor

PBL- Peripheral blood lymphocyte

PFP-phosphate; phosphotransferase (PFP is an exclusively cytosolic enzyme that catalyses the phosphorylation of fructose-6-phosphate to fructose-1,6bisphosphate in the glycolytic direction, and the de-phosphorylation of fructose-1,6-bisphoshate to fructose-6-phosphate in the gluconeogenic reaction)

PRF- Platelet Rich Fibrin

PFR - Poreforming Protein

TIL- Tumour-infiltrating Iymphocyte, a white blood cell that has migrated to a tumour 


\section{Sažetak}

Istražena je literatura o ulozi perforina u medicini. Prvi je korak bio sustavno pretraživanje tako da se prepoznaju relevantne studije koje su objavljene od 2001. i 2019. u sljedećim elektroničkim bazama: EBSCOhost, Scopus, ScienceDirect, Web of Science i Elsevier. Analizom dostupne literature zaključuje se da perforin igra važnu ulogu u citotoksičnoj aktivnosti prirodnoubilačkih stanica i CD8+ stanica. Prirodnoubilačke stanice i CD8+ služe se istim mehanizmom za uništenjem ciljnih stanica. $U$ ovom radu navedena je bolest hemofagocitičnalimfohistiocito za (HLH) koju obilježavaju iznimne abnormalnosti u području imunosnog sustava. Poanta je u tome da ovu bolest uzrokuje genska mutacija perforina. Ključ je u primjeni pravilno senzibiliziranih dendritičnih stanica (DCs) koje mogu biti također učinkovite u imunoterapiji protiv raka. GIH inducira sazrijevanje i aktivaciju DCs. GIH-DCs pokazuju povećanu citotoksičnu aktivnost te veću ekspresiju perforina i granzima. Teorijska istraživanja pokazala su da je učinkovita aktivnost protiv raka inducirana kada se DCs senzibiliziraju $s \gamma$-ozračenim stanicama raka. Tako se putem izravnog povećanja citotoksičnosti i neizravne aktivacije T-stanica možda još može djelovati antitumorski. Predlažem da se nastavi znanstveno istraživanje o ulozi perforina u budućnosti.
Ključne riječi: perforin, limfociti, ciljna stanica, granzimi, literatura 